\title{
Herança da Resistência à Antracnose na Cultivar de Feijoeiro Comum Cornell 49-242
}

\author{
Ana Lilia A. Marin'1, Márcia Regina Costa ${ }^{1}$, Henrique Menarim, Maurilio A. \\ Moreira $^{2}$ \& Everaldo G. Barros ${ }^{3}$
}

${ }^{1}$ Instituto de Biotecnologia Aplicada à Agropecuária - BIOAGRO, e-mail: anaalzatem@ yahoo.com.br; ${ }^{2}$ Departamento de Bioquímica e Biologia Molecular, e-mail: moreira@ ufv.br, ${ }^{3}$ Departamento de Biologia Geral, Universidade Federal de Viçosa, e-mail: ebarros@ufv.br. CEP 36571-000, Viçosa, MG, fax (031)3899-2864

(Aceito para publicação em 09/04/2003)

Autor para correspondência: Ana Lilia Alzate-Marin

ALZATE-MARIN, A.L., COSTA, M.R., MENARIM, H., MOREIRA, M.A. \& BARROS, E.G. Herança da resistência à antracnose na cultivar de feijoeiro comum Cornell 49-242. Fitopatologia Brasileira 28:302-306. 2003.

\section{RESUMO}

A cultivar de feijoeiro (Phaseolus vulgaris) Cornell 49-242, possuidora do gene de resistência $\mathrm{Co}-2$ (Are), é uma das mais antigas fontes de resistência à antracnose, causada por Colletotrichum lindemuthianum. Visando a utilização desta fonte no programa de piramidação de genes em cultivares do tipo "carioca" do BIOAGRO/UFV, este trabalho teve como objetivos: (1) definir o padrão de herança da resistência da cultivar de feijoeiro Cornell 49-242 em cruzamentos com cultivares suscetíveis às raças 81 (Rudá) e 65 (Rudá e Ouro Negro) de C. lindemuthianum e (2) avaliar o marcador RAPD OPQ04 ${ }_{1440 \mathrm{C}}$ ligado ao gene $\mathrm{Co}-2 \mathrm{em}$ populações $F_{2}$ do cruzamento Rudá vs. Cornell 49-242. Os resultados indicaram que três genes dominantes, sendo dois de caráter complementar, controlam a resistência ao patótipo 81 de C. lindemuthianum, enquanto que um gene dominante e um recessivo controlam a resistência ao patótipo 65. O marcador $\mathrm{OPQ}_{1440 \mathrm{C}}$, previamente identificado como ligado ao gene $\mathrm{Co}-2$, pode ser usado, na prática, nesta população, para selecionar linhagens $\mathrm{F}_{2: 3}$ contendo o gene $\mathrm{Co}-2$.

Palavras-chave adicionais: Colletotrichum lindemuthianum, Phaseolus vulgaris, marcadores moleculares, genes da resistência.

\section{ABSTRACT}

Inheritance of Resistance to Anthracnose in the Common Bean Cultivar Cornell 49-242

The cultivar Cornell 49-242 of common bean (Phaseolus vulgaris) harbors the Co-2 gene (Are) one of the oldest sources of resistance to anthracnose, caused by Colletotrichum lindemuthianum. Aiming to use this gene in the breeding program being conducted at the BIOAGRO/UFV, by pyramiding resistance genes in "cariocatype" cultivars, this work had the following objectives: (1) to determine the inheritance pattern of resistance of cultivar Cornell 49-242 in crosses with cultivars Rudá (susceptible to $C$. lindemuthianum races 81 and 65) and Ouro Negro (susceptible to race 65 ) and (2) to evaluate the RAPD marker OPQ04 ${ }_{1440 \mathrm{C}}$ linked to the $C o-2$ gene in $\mathrm{F}_{2}$ populations derived from the cross Rudá vs. Cornell 49-242. The results indicated the involvement of three independent dominant genes, two of which behave as complementary factors that control resistance to pathotype 81 , and one dominant and one recessive genes which control resistance to pathotype 65 . The marker OPQ04 $4_{1440 \mathrm{C}}$ previously identified as linked to $\mathrm{Co}-2$ gene can be used to select $\mathrm{F}_{2: 3}$ lines in these populations for the presence or absence of the $\mathrm{Co}-2$ gene.
Organismos fitopatogênicos são grandes responsáveis por perdas significativas nas lavouras de feijoeiro (Phaseolus vulgaris $\mathrm{L}$.), chegando muitas vezes a inviabilizar a cultura em determinadas regiões. O fungo Colletotrichum lindemuthianum (Sacc. \& Magn.) Scrib., agente causal da antracnose do feijoeiro comum, encontra-se entre os principais patógenos desta cultura. Este patógeno apresenta grande diversidade e muitos patótipos já foram identificados no Brasil e no mundo. As perdas causadas pela antracnose podem chegar a $100 \%$, principalmente quando são empregadas sementes infetadas de cultivares suscetíveis, podendo ser maiores quanto mais precoce for o aparecimento da doença na lavoura. Além de diminuir o rendimento da cultura, a antracnose deprecia a qualidade do produto por ocasionar manchas no grão, tornando-o impróprio para o consumo. No Brasil, a antracnose é prevalecente nos principais estados produtores como Rio Grande do Sul, Santa Catarina, Paraná, São Paulo, Minas Gerais, Bahia e Pernambuco, sendo importante ainda nos estados do Espírito Santo, Alagoas, Sergipe e Paraíba (Rava et al., 1994).

No passado, a cultivar Cornell 49-242, fonte do gene de resistência à antracnose do feijoeiro Are ou Co-2 (Basett, 1996), foi extensivamente utilizada e hoje faz parte das genealogias de um grande número de cultivares e linhagens provenientes do CIAT (Alzate-Marin et al., 2001). Na caracterização com 35 patótipos identificados no Brasil entre os anos de 1994 e 2000, a cultivar Cornell 49-242 apresentou resistência aos patótipos $1,7,23,55,64,65,67,69,71,81,83,86,87,97,101,102,117,119$, 320, 339, 343, 453 (Rava et al., 1994; Andrade et al., 1999) e 31 (Thomazella et al., 2000) e suscetibilidade aos patótipos 8, 72, 73, 75, 79, 89, 95, 121, 137, 217, 249 e 585 (Rava et al., 1994; 
Andrade et al., 1999). Andrade et al. (1999) demonstraram que os patótipos $65,72,73,81$ e 89 foram os mais freqüentes no Brasil, sendo que os patótipos 65, 73 e 81 tiveram a maior distribuição nos Estados analisados. Assim, em termos gerais, a cultivar Cornell 49-242 tem um amplo espectro de resistência, apresentando incompatibilidade com 22 dos 35 patótipos identificados nesses trabalhos, incluídos os patótipos 65 e 81 . Estes dados mostram a importância desta cultivar como fonte de resistência à antracnose do feijoeiro no Brasil, tanto em programas de melhoramento convencionais quanto naqueles que visem a piramidação de genes de resistência de espectro complementar, com o auxílio de marcadores moleculares.

Os marcadores moleculares do tipo RAPD ("Random amplified polymorphic DNA”) OPH20 ${ }_{450 \mathrm{C}}$, OPQ4 ${ }_{1440 \mathrm{C}}$ e B355${ }_{1000 \mathrm{C}}$, ligados ao gene $\mathrm{Co}-2$ de isolinhas altamente endogâmicas derivadas da cultivar Cornell 49-242, foram previamente identificados (Adam-Blondon et al., 1994; Young \& Kelly, 1996). Estes marcadores podem ser úteis em programas de melhoramento que utilizem este gene como fonte de resistência à antracnose.

No programa de melhoramento do feijoeiro do BIOAGRO/UFV o gene Co-2 (Are) é um dos genes que serão piramidados no background genético Rudá, feijão de tipo comercial "carioca". Assim, este trabalho teve como objetivos: 1) determinar o padrão de herança da resistência da cultivar Cornell 49-242 em cruzamentos com as cultivares Rudá e Ouro Negro, e 2) avaliar o marcador RAPD OPQ0 $4_{1440 \mathrm{C}}$ ligado ao gene $C o-2$ da cultivar Cornell 49-242, em populações segregantes do cruzamento Rudá vs. Cornell 49-242.

Os patótipos 65 e 81 de $C$. lindemuthianum, usados neste trabalho estão incluídos no grupo de 25 patótipos identificados no Brasil (Rava et al., 1994). As colônias monospóricas originais foram fornecidas pelos Drs. Carlos A. Rava e Aloísio Sartorato (Embrapa Arroz e Feijão, Goiânia, GO, Brasil) e mantidas na micoteca do BIOAGRO/UFV. O inóculo de cada patótipo foi produzido em tubos de ensaio contendo vagens esterilizadas e parcialmente imersas em meio ágar-água, as quais, após serem inoculadas com os patótipos de $C$. lindemuthianum desejados, foram incubadas por dez dias sob temperatura de $23^{\circ} \mathrm{C}$.

O material genético utilizado como fonte de resistência aos patótipos 65 e 81 de $C$. lindemuthinum foi a cultivar Cornell 49-242, cedida pelo Centro Internacional de Agricultura Tropical (CIAT, Colômbia). A cultivar suscetível ao patótipo 81 de $C$. lindemuthianum usada nos cruzamentos foi a cultivar Rudá, a qual foi desenvolvida pelo CIAT, a partir do cruzamento entre as cultivares Carioca e Rio Tibagi, sendo introduzida no Brasil como linhagem A 285, pela Embrapa - Arroz e Feijão (Goiânia, GO). As cultivares suscetíveis ao patótipo 65 de C. lindemuthianum usadas nos cruzamentos com Cornell 49-242 foram as cultivares Rudá e Ouro Negro. Ouro Negro é uma cultivar de semente preta introduzida de Honduras, conhecida também como Honduras 35, que apresenta resistência a todos os patótipos de $C$. lindemuthianum identificados no Brasil com exceção do patótipo 65 (Arruda et al., 2001). A cultivar Cornell 49-242 foi usada como genitor masculino nos cruzamentos. Os cruzamentos e as populações $\mathrm{F}_{1}, \mathrm{~F}_{2}$ e $\mathrm{F}_{3}$ (derivados do cruzamento Rudá vs. Cornell 49-242) e $\mathrm{F}_{1}$ e $\mathrm{F}_{2}$ (derivados do cruzamento Ouro Negro vs. Cornell 49-242) foram conduzidos em casa de vegetação.

Três experimentos foram realizados para avaliar a herança da resistência aos patótipos 81 e 65 de $C$. lindemuthianum. No primeiro, 72 sementes $\mathrm{F}_{2}$ (Rudá vs. Cornell 49-242), e 20 sementes de cada genitor foram semeadas em casa de vegetação. Antes da inoculação foi coletada uma folha primária de todas as plantas, as quais foram conservadas a $-80^{\circ} \mathrm{C}$ para posterior extração de DNA e avaliação de marcadores moleculares. Quinze dias após a semeadura, as plantas foram inoculadas com uma suspensão de inóculo contendo $1,2 \times 10^{6}$ esporos/ml do patótipo 81 , nas faces abaxial e adaxial de uma das folhas primárias de cada uma das plantas, com o auxílio de um aparelho deVilbis No. 15 . As plantas foram incubadas por sete dias em câmara de nevoeiro, a qual foi mantida entre 20 e $22^{\circ} \mathrm{C}$ e $100 \%$ de umidade relativa. Após este período, cada planta foi avaliada visualmente para os sintomas da doença usando uma escala de 1 a 9, na qual 1 (um) foi atribuído a plantas sem sintomas visíveis e 9 (nove) a plantas severamente doentes ou mortas. As plantas com graus de 1 a 3 foram consideradas resistentes, e as que apresentaram graus de 4 a 9 foram classificadas como suscetíveis (Rava et al., 1993). No segundo experimento, foram semeadas em casa de vegetação, 79 sementes $\mathrm{F}_{2}$ (Rudá vs. Cornell 49-242). A autofecundação das plantas correspondentes gerou 79 famílias $\mathrm{F}_{2: 3}$. Doze sementes de cada uma destas famílias $\mathrm{F}_{2 \cdot 3}$, e 95 e 56 sementes dos genitores Rudá e Cornell 49-242, respectivamente, foram semeadas, em casa de vegetação. Quinze dias após a semeadura, as 1.099 plantas resultantes foram inoculadas com uma suspensão de inóculo contendo 1,2 × $10^{6}$ esporos $/ \mathrm{ml}$ do patótipo 81. Os demais procedimentos de incubação, avaliação e classificação foram similares aos do primeiro experimento. No terceiro experimento, foram plantadas em casa de vegetação, 12 sementes de cada genitor e 50 sementes $\mathrm{F}_{2}$ (Rudá vs. Cornell 49-242). Separadamente, foram plantadas 20 sementes de cada genitor e 95 sementes $\mathrm{F}_{2}$ do cruzamento Ouro Negro vs. Cornell 49-242. As plantas destas duas populações foram inoculadas com o patótipo 65 de $C$. lindemuthianum. Os demais procedimentos de incubação, avaliação e classificação foram similares aos do primeiro experimento.

Amostras de DNA foram extraídas dos genitores e de cada indivíduo da população $\mathrm{F}_{2}$ derivada do cruzamento Rudá vs. Cornell 49-242, de acordo com a metodologia descrita por Doyle \& Doyle (1990). As reações de amplificação foram efetuadas em termociclador Perkin-Elmer, modelo 9600, de acordo com Williams et al. (1990). Os produtos de amplificação foram separados em gel de agarose $1,2 \%$ contendo $10 \mathrm{mg} / \mathrm{ml}$ de brometo de etídio, imerso em tampão TBE (Tris-Borato 90 mM, EDTA $1 \mathrm{mM}, \mathrm{pH} 8,0)$. As bandas de DNA foram visualizadas sob luz ultravioleta e fotodigitalizadas com o sistema de fotodocumentação Eagle Eye II (Stratagene). 
O teste de Qui-quadrado foi usado para definir a herança da resistência a antracnose do feijoeiro da cultivar Cornell 49242 , em populações $F_{2}$ e famílias $F_{3}$. A freqüência de recombinação entre o marcador OPQ4 ${ }_{1440 \mathrm{C}}$ e o gene de resistência foi calculada usando 72 indivíduos da população $\mathrm{F}_{2}$ originados do cruzamento entre Rudá e Cornell 49-242, inoculados com o patótipo 81 de $C$. lindemuthianum. A distância foi estimada pelo programa MAP-MAKER III, com um lod score mínimo de 3,0 (Lander et al., 1987).

A razão de 57:7 (R:S) encontrada nas plantas $F_{2}$ e nas famílias $\mathrm{F}_{3}$ derivadas do cruzamento Rudá vs. Cornell 49-242 indica que três genes dominantes independentes, sendo dois complementares, estão envolvidos na resistência ao patótipo 81 de C. lindemuthianum (Tabela 1). Assim, Cornell 49-242 possui dois genes que conferem resistência ao patótipo 81 de $C$. lindemuthianum, o primeiro não apresenta relação de epistasia. Tanto o segundo gene de Cornell 49-242 quanto um gene presente na cultivar Rudá conferem resistência só quando ambos estão presentes. $\mathrm{O}$ alelo recessivo de um destes genes é epistático sobre o alelo dominante do outro gene, gerando uma reação de suscetibilidade. A razão de 1:3 (R:S) observada na segregação das plantas $\mathrm{F}_{2}$ (Rudá vs. Cornell 49-242) e de 3:1 (Ouro Negro vs. Cornell 49-242), inoculadas com o patótipo 65 (Tabela 2), mostra que um gene recessivo e um dominante estão envolvidos na resistência da cultivar Cornell 49-242 a este patótipo.
A cultivar Cornell 49-242 é uma das mais antigas fontes de resistência à antracnose do feijoeiro comum, sendo o gene (ou loco complexo) Co-2 inicialmente chamado de Are identificado por Mastenbroek em 1960 (Bassett, 1996). Diversas referências mostram tanto a simplicidade como a complexidade na genética da resistência envolvendo esta fonte. Trabalhos de Muhalet et al. (1981) e Peloso (1987) mostraram que nos cruzamentos com Cornell 49-242, a relação de segregação de 3:1 é a mais freqüente, mas segregações de 57:7, 9:7 e 7:9 foram também observadas em populações derivadas dos cruzamentos entre Cornell 49-242 e as cultivares Kaboon, Costa Rica e Michelite, inoculadas com os patótipos gama, BA -10 delta, e BA-5, respectivamente. Segregações que mostraram dominância e recessividade podem ser explicadas pela ação de multigenes que compõem o loco complexo Co-2 (Geffroy et al., 1998). Assim, diferentes genes que compõem esse loco poderiam ser detectados quando diferentes cruzamentos e diferentes patótipos são estudados.

O marcador OPQ04 ${ }_{1440 \mathrm{C}}$ identificado como ligado ao gene Co-2 na isolinha Andina K86002 a 2,0 $1,4 \mathrm{cM}$ e na isolinha mesoamericana A4512 a 5,5 \pm 2,3 cM (Young \& Kelly, 1996), ambas descendentes de Cornell 49-242, foi testado em amostras de DNA de 64 plantas $\mathrm{F}_{2}$ resistentes e oito suscetíveis (Rudá vs. Cornell 49-242) ao patótipo $81 \mathrm{de} C$. lindemuthianum. Como resultado foi observada uma distância de $33,4 \mathrm{cM}$ entre o gene de resistência e o marcador (Tabela 1, Figura 1). A grande

TABELA 1 - Herança da resistência da cultivar de feijoeiro (Phaseolus vulgaris) Cornell 49-242 ao patótipo 81 de Colletotrichum lindemuthianum, no cruzamento com a cultivar Rudá

\begin{tabular}{|c|c|c|c|c|c|c|c|}
\hline \multirow{2}{*}{ Pedigree } & \multirow{2}{*}{ Geração } & \multicolumn{2}{|c|}{$\mathrm{N}^{\circ}$ de Plantas } & \multirow{2}{*}{ Relação Esperada } & \multirow{2}{*}{$\chi^{2}$} & \multirow{2}{*}{$\mathbf{P}$} & \multirow{2}{*}{$\mathbf{c M}^{\mathrm{a}}$} \\
\hline & & Resistente & Suscetível & & & & \\
\hline Rudá & $\mathrm{P}_{1}$ & & 20 & - & - & - & - \\
\hline Cornell 49-242 & $\mathrm{P}_{2}$ & 20 & & - & - & - & - \\
\hline Rudá x Cornell 49-242 & $\mathrm{F}_{2}$ & 64 & 8 & $57: 7$ & 0,0022 & 96,23 & \\
\hline OPQ0 $4_{1440 \mathrm{C}^{\mathrm{b}}}$ & $\mathrm{F}_{2}$ & $54(+)^{\mathrm{c}}, 10(-)^{\mathrm{d}, \mathrm{e}}$ & $5(-), 3(+)^{\mathrm{f}}$ & $3: 1$ & 1,77 & 31,73 & $33,4 \pm 1,53^{\mathrm{a}}$ \\
\hline Rudá & $\mathrm{P}_{1}$ & & 95 & - & - & - & - \\
\hline Cornell 49-242 & $\mathrm{P}_{2}$ & 56 & & - & - & - & - \\
\hline Rudá x Cornell 49-242 & $\mathrm{F}_{2: 3}$ & 70 famílias & 9 famílias & $57: 7$ & 0,02 & 89,69 & - \\
\hline
\end{tabular}

aDistâncias genéticas em centiMorgans (cM) e desvio padrão

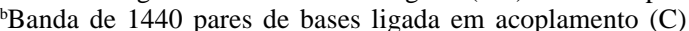

'Presença da banda do marcador OPQ04 $4_{1440}$

${ }^{\mathrm{d}}$ Ausência da banda do marcador OPQ04 $4_{1440 \mathrm{C}}$

ePlantas resistentes sem banda (-) têm o segundo gene da cultivar Cornell 49-242 detectado neste trabalho ou são recombinantes

fPlantas suscetíveis com banda correspondem a plantas recombinantes

TABELA 2 - Herança da resistência da cultivar de feijoeiro (Phaseolus vulgaris) Cornell 49-242 ao patótipo 65 de Colletotrichum lindemuthianum, nos cruzamentos com as cultivares Rudá e Ouro Negro

\begin{tabular}{|c|c|c|c|c|c|c|}
\hline \multirow{2}{*}{ Pedigree } & \multirow{2}{*}{ Geração } & \multicolumn{2}{|c|}{$\mathbf{N}^{\circ}$ de Plantas } & \multirow{2}{*}{ Relação Esperada } & \multirow{2}{*}{$\chi^{2}$} & \multirow{2}{*}{$\mathbf{P}$} \\
\hline & & Resistente & Suscetível & & & \\
\hline Rudá & & & 12 & & & \\
\hline Cornell 49-242 & & 12 & & & & \\
\hline Rudá x Cornell 49-242 & & 9 & 41 & $1: 3$ & 1,30 & 25,99 \\
\hline Ouro Negro & $\mathrm{P}_{1}$ & - & 20 & - & - & - \\
\hline Cornell 49-242 & $\mathrm{P}_{2}$ & 20 & - & - & - & - \\
\hline Ouro Negro x Cornell 49-242 & $\mathrm{F}_{2}$ & 69 & 26 & $3: 1$ & 0,28 & 59,39 \\
\hline
\end{tabular}




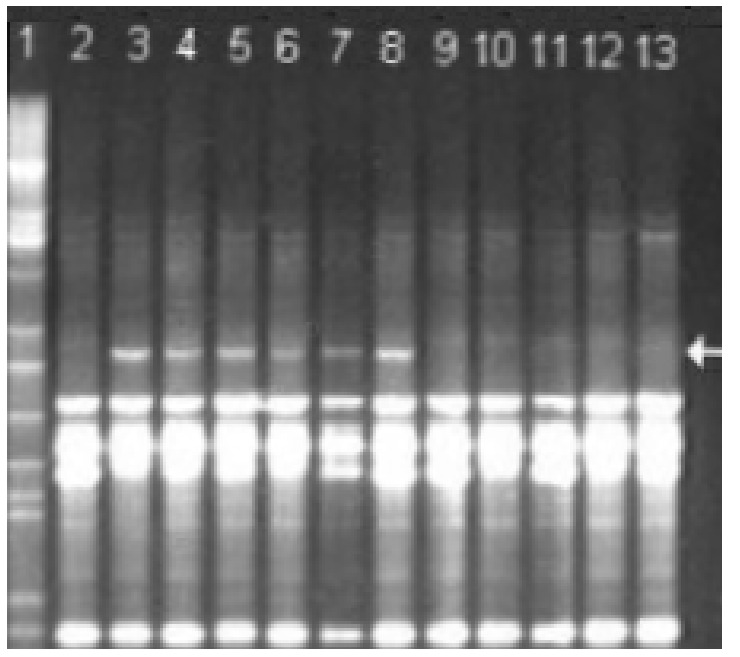

FIG. 1 - Análise eletroforética dos produtos de amplificação do DNA de cultivares de feijoeiro (Phaseolus vulgaris) mostrando o marcador $\mathrm{OPQ} 4_{1440 \mathrm{C}}$. As canaletas correspondem a: (1) DNA de fago lambda clivado com as enzimas EcoRI, BamHI e HindIII (marcador de tamanho), (2) Rudá, (3) Cornell 49-242, (4-8) plantas $\mathrm{F}_{2}$ resistentes e (9-13) plantas $F_{2}$ suscetíveis ao patótipo 81 de Colletotrichum lindemuthianum provenientes do cruzamento Rudá vs. Cornell 49242. A seta indica a banda de 1.440 pares de bases do primer OPQ04 ligada em acoplamento $(\mathrm{C})$ ao loco complexo $\mathrm{Co}-2$ da cultivar Cornell 49-242.

distância entre o marcador e o gene é devida ao fato da população estar segregando para três genes, dois derivados da cultivar Cornell 49-242, como já mencionado, ou seja, esta população $\mathrm{F}_{2}$ não pode ser usada para fins de mapeamento genético, uma vez que a população ideal para este fim deve segregar para um só gene $(3: 1)$. Assim, a utilidade prática do marcador OPQ04 ${ }_{1440 \mathrm{C}}$ nesta população está no seu uso para a separação dos genes nas famílias $\mathrm{F}_{2: 3}$. As plantas $\mathrm{F}_{2}$ resistentes que apresentam a banda OPQ0 $4_{1440 \mathrm{C}}$ possuiriam o gene $C o-2 \mathrm{e}$ aquelas plantas resistentes que não apresentam a banda, possuiriam os outros genes de resistência provenientes de Rudá e Cornell 49-242 detectados no estudo de herança da resistência ao patótipo 81 .

Quando se usa a cultivar Cornell 49-242 como fonte de resistência à antracnose, diferentes genes dominantes ou recessivos podem ser observados de acordo com o cruzamento ou patótipo utilizado. Isso é devido à complexidade do loco Co-2, além da interação de outros genes independentes também presentes na cultivar Cornell 49-242. Esta situação dificulta a identificação dos genes presentes nas cultivares melhoradas que tenham usado esta fonte como genitor. O uso de marcadores moleculares previamente identificados como ligados a $C o-2$, pode ser importante na seleção de linhagens possuindo tal loco. Uma ferramenta que ajudaria a confirmar se estes genes foram efetivamente incorporados em novas linhagens, seria a comparação dos espectros de resistência das cultivares derivadas com relação ao espectro de resistência da cultivar Cornell 49-242, que é resistente a 22 patótipos de $C$. lindemuthianum.

\section{AGRADECIMENTOS}

Este trabalho foi financiado pelo CNPq. A primeira autora foi financiada pela FAPEMIG e IICA. Márcia R. Costa e Henrique Menarim tiveram bolsa de IC da FAPEMIG e CNPq.

\section{REFERÊNCIAS BIBLIOGRAFICAS}

ADAM-BLONDON, A., SÉVIGNAC, M., BANNEROT, H. \& DRON, M. SCAR, RAPD and RFLP markers linked to ARE, a simple gene conferring resistance to $C$. lindemuthianum, the causal agent of antracnose in french bean. Theorical and Applied Genetics 88:865-870. 1994

ALZATE-MARIN, A.L., COSTA, M. R., SARTORATO, A., RAVA, C., BARROS E.G. \& MOREIRA, M.A. Use of markers as a tool to investigate the presence of disease resistance genes in common bean cultivars. Crop Breeding and Applied Biotechnology. 1:125-133. 2001

ANDRADE, E.M., COSTA, J.G.C. \& RAVA, C.A. Variabilidade patogênica de isolados de Colletotrichum lindemuthianum de algumas regiões brasileiras. In: Embrapa Arroz e Feijão (Ed.). Reunião Nacional de Pesquisa de Feijão-RENAFE Anais -.Salvador. Embrapa Arroz e Feijão, Documento 99. 1999. pp.242-244.

ARRUDA, K.M., ALZATE-MARIN, A.L., BARROS, E.G. \& MOREIRA, M.A. Caracterização dos cultivares de feijoeiro Ouro Negro e Seleção 1308 com raças de Colletotrichum lindemuthianum. Fitopatolologia Brasileira 26:381. 2001. (Resumo)

BASSETT, M.J. List of genes - Phaseolus vulgaris. Annual Report Bean Improvement Cooperative 39:1-9. 1996.

DOYLE, J. J. \& DOYLE, J.L. Isolation of plant DNA from fresh tissue. Focus 12:13-15. 1990.

GEFFROY, V., CREUSOT, F., FALQUET, J., SEVIGNAC, M., ADAM-BLONDON, A. F., BANNEROT, H., GEPTS, P. \& DRON, M. A family of LRR sequences in the vicinity of the $\mathrm{Co}-2$ locus for anthracnose resistance in Phaseolus vulgaris and its potential use in marker assisted selection. Theoretical and Applied Genetics 96:494-502. 1998.

LANDER, E.S., GREEN, P., ABRAHAMSOM J., BARLOW, A., DALY, M.J., LINCOLN, S.E. \& NEWBURG, L. Mapmaker: An interactive computer package for constructing genetic linkage maps of experimental and natural populations. Genomics 1:174-181. 1987.

MUHALET, C., ADAMS, M., SAETTLER, A. \& GHADERI, A. Genetic system for the reaction of field beans to Beta, Gamma, and Delta races of Colletotrichum lindemuthianum. Journal American Society Horticultural Science106:601-604.1981.

PELOSO, M.J. Del. Genética da reação do feijoeiro ( $C$. lindemuthianum.) a três raças fisiológicas de Colletotrichum lindemuthianum L. (Sacc. et Magn) Scrib. (Tese Doutorado). Genética e Melhoramento - Universidade Federal de Viçosa. 1987.

RAVA, C.A., MOLINA, J., KAUFFMANN, M. \& BRIONES, I. Determinación de razas fisiológicas de Colletotrichum lindemuthianum en Nicarágua. Fitopatologia Brasileira 18:388-391. 1993.

RAVA, C.A., PURCHIO, A.F. \& SARTORATO, A. Caracterização de Patótipos de Colletotrichum lindendemuthianum que ocorreram em algumas regiões produtoras de feijoeiro comum. Fitopatologia 
Brasileira 19:167-172. 1994.

THOMAZELLA C., GONÇALVES-VIDIGAL, M.C., VIDA, J. B., VIDIGAL FILHO, P.S. \& RIMOLDI, F. Identification of Colletotrichum lindemuthianum races in Phaseolus vulgaris L. Annual Report Bean Improvement Cooperative 43:82-83. 2000. WILLIAMS, J., KUBELIK, A., LIVAK, K., RAFALSKI, A. \&
TINGEY, S. DNA polymorphism amplified by arbitrary primers are useful as genetic markers. Nucleic Acids Research 18:6531-6535. 1990.

YOUNG, R. \& KELLY, J.D. RAPD Markers flanking the Are gene for anthracnose resistance in common bean. Journal American Society Horticultural Science 121:37-41. 1996. 